\title{
BIOSYNTHESIS OF FORMYCIN
}

FORMATION OF FORMYCIN FROM FORMYCIN B

\author{
Kōzō Ochi, Shigetaka Yashima and Yoshitomo Eguchi \\ Department of Microbial Engineering and Technology, \\ Faculty of Agriculture, Hokkaido University, \\ Sapporo, Japan
}

(Received for publication September 16, 1975)

\begin{abstract}
1. In replacement culture with a formycin-producing strain, Streptomyces sp. MA 406-A-1, exogenously added formycin B was quantitatively converted to formycin and the conversion was inhibited by adding the chromophore moiety of formycin.

2 . The in vitro experiments revealed that the novel enzyme(s) catalyzing the formation of fumarate and formycin from aspartate and formycin B, but not from formycin B monophosphate, was present in this organism. The action of the partially purified enzyme(s) was also inhibited by the chromophore moiety of formycin, whereas the moiety showed no inhibitory effect on the actions of adenylosuccinate synthetase and adenylosuccinate lyase.

3. Adenine auxotrophs lacking either adenylosuccinate synthetase or adenylosuccinate lyase were derived from strain MA406-A-1 and these auxotrophs were found to readily convert formycin B to formycin in replacement culture.

From these results, it was estimated that, under the conditions of replacement culture, formycin B would be converted to formycin in vivo by the action of novel enzyme(s) rather than by the action of enzyme system including adenylosuccinate synthetase and adenylosuccinate lyase.
\end{abstract}

The formycin family produced by Nocardia interforma and other organisms is a group of pyrazolopyrimidine nucleosides containing a C-riboside linkage in the molecule, and formycin, formycin B or oxoformycin B are structural analogs of adenosine, inosine or xanthosine, respectively. ${ }^{1-8)}$ In the first stage of the formycin family-biosynthesis, i.e. the biosynthesis of pyrazolopyrimidine ring in $N$. interforma, it has been estimated by Kunimoto et al. that the ring may be synthesized via another pathway than that of purine nucleotides. ${ }^{7)}$ As recently reported, this estimation was supported in the authors' experiments with another formycinproducing strain, Streptomyces sp. MA406-A-1, and it was suggested that the metabolism of lysine, glutamate and aspartate may be closely related to the biosynthesis of formycin in this organism. ${ }^{8)}$ On the later part of formycin family-biosynthesis in $N$. interforma, it has been reported that the biosynthesis may take place via the following pathway: ? $\rightarrow$ formycin B monophosphate $\rightarrow$ formycin monophosphate $\rightarrow$ formycin $\rightarrow$ formycin B $\rightarrow$ oxoformycin B. ${ }^{{ }^{2}}$ During the course of studies on the biosynthesis of formycin in S. sp. MA406-A-1, this organism was found to convert efficiently formycin B to formycin in replacement culture, and it was also confirmed that this organism contained the enzyme(s) catalyzing the amination of formycin $\mathrm{B}$ to form formycin.

The present report concerns with the relation between the conversion ratio of formycin $\mathrm{B}$ to formycin in replacement culture and the activity of formycin B-aminating enzyme(s), adenylosuccinate synthetase or adenylosuccinate lyase. 


\section{Materials and Methods}

\section{Organisms}

Streptomyces sp. MA406-A-1 and Xanthomonas oryzae were obtained from the Institute of Microbial Chemistry, Tokyo. Adenine auxotrophs were derived from the strain MA406-A-1 by treatment with $\mathrm{N}$-methyl-N'-nitro-N-nitrosoguanidine. ${ }^{10)}$

\section{Cultivation and Media}

Cultivation in MPY-medium and preparation of washed cells of strain MA406-A-1 and auxotrophs were carried out as previously reported, except that the former and the latter were incubated for 11 and 18 hours, respectively. ${ }^{8)}$ Conversion of formycin $\mathrm{B}$ to formycin was performed in the conversion-medium under the previously reported conditions for replacement culture. ${ }^{8)}$

\section{Determination}

Total concentration of formycin and formycin B was estimated by a cylinder-plate method with $X$. oryzae as a test organism.

Formycin concentration was measured by column chromatography. To $1 \mathrm{ml}$ of the preparation containing formycin was added $3 \mathrm{ml}$ of $25 \mathrm{mM} \mathrm{NH}_{4} \mathrm{Cl}$ (adjusted to $\mathrm{pH} 10.5$ with conc. $\left.\mathrm{NH}_{4} \mathrm{OH}\right)$ and the mixture was introduced into a water-jacketed column $\left(\phi 7 \mathrm{~mm} \times 50 \mathrm{~cm} ; 50^{\circ} \mathrm{C}\right)$ of Dowex $1 \times 4(200 \sim 400$ mesh) in the chloride form. The elution was done with $1 \mathrm{~mm} \mathrm{HCl}$ in $25 \mathrm{mM} \mathrm{NH}_{4} \mathrm{Cl}$ at a flow rate of $30 \mathrm{ml}$ per hour. The optical absorption of the effluent was continuously recorded at 230, 260 and $280 \mathrm{~nm}$ in a Hitachi UV-VIS Effluent Monitor Model034. The fractions containing formycin were pooled and formycin concentration was determined by measuring the optical density of the solution at $295 \mathrm{~nm}$. In this procedure, formycin was recovered almost quantitatively.

The activity of adenylosuccinate synthetase or adenylosuccinate lyase was measured by a slightly modified method of LieBerman (assay III) ${ }^{11)}$ or CARTER ${ }^{12)}$, respectively.

The activity of formycin B-aminating enzyme(s) was determined by measuring the initial velocity of appearance of $\mathrm{U}-^{14} \mathrm{C}$-fumarate produced in the reaction at $35^{\circ} \mathrm{C}$. The reaction mixture contained, in $0.5 \mathrm{ml}$, formycin $\mathrm{B}(0.5 \mu \mathrm{mole})$, U- ${ }^{14} \mathrm{C}$-aspartate $(1 \mu \mathrm{mole} ; 0.1 \mu \mathrm{Ci}), \mathrm{MgSO}_{4}$. $7 \mathrm{H}_{2} \mathrm{O}(0.5 \mu \mathrm{mole})$, glycine buffer $(\mathrm{pH} 8.5,5.0 \mu \mathrm{moles})$ and enzyme solution. The reaction was started by adding formycin B and stopped by adding $50 \mu \mathrm{l}$ of $20 \%$ perchloric acid and then the solution was centrifuged. The supernatant solution was neutralized with conc. $\mathrm{KOH}$ and centrifuged. In the supernatant solution thus prepared, none of any other radioactive compounds than fumarate or aspartate was detectable by paper chromatography with seven solvent systems. An aliquot of the supernatant solution was spotted on a filter paper (Tōyō Roshi No. 51A), and ascending paper chromatography was done at room temperature for $10 \sim 16$ hours with a solvent system of $n$-butanol, acetic acid and water $(4: 1: 2 ; \mathrm{v} / \mathrm{v})$. The areae of the paper corresponding to the positions of fumarate ( $\operatorname{Rf} 0.83$ ) and aspartate ( $\operatorname{Rf} 0.21$ ) were cut off and the radioactivity of each paper tip was measured by the method reported previously. ${ }^{8}$ ) The amount of fumarate formed was calculated from the ratio of radioactivity of fumarate to that of aspartate. It was concluded that a linear formation of fumarate continued until 0.20 $\mu$ mole of fumarate was formed in $0.5 \mathrm{ml}$ of the reaction mixture.

A unit of these enzymes was defined as amount of enzyme catalyzing the formation of one $\mu$ mole of product per minute under the assay conditions described.

Protein concentration was determined by the method of LOWRY et al. ${ }^{14)}$

\section{Chemicals}

Formycin and formycin B were obtained from Meiji Seika Co., Ltd., Tokyo. The chromophore moiety (7-amino-pyrazolo[4,3-d]pyrimidine: DFA-4) of formycin was prepared from formycin by the method of Kawamura et al. ${ }^{13)}$

Formycin 5'-monophosphate was systhesized chemically according to the procedure described by WARD et al. ${ }^{15)}$ Formycin B 5 '-monophosphate was synthesized in the following manner. 
Fig. 1. Infrared spectrum of the preparation ( $\mathrm{KBr}$ tablet)

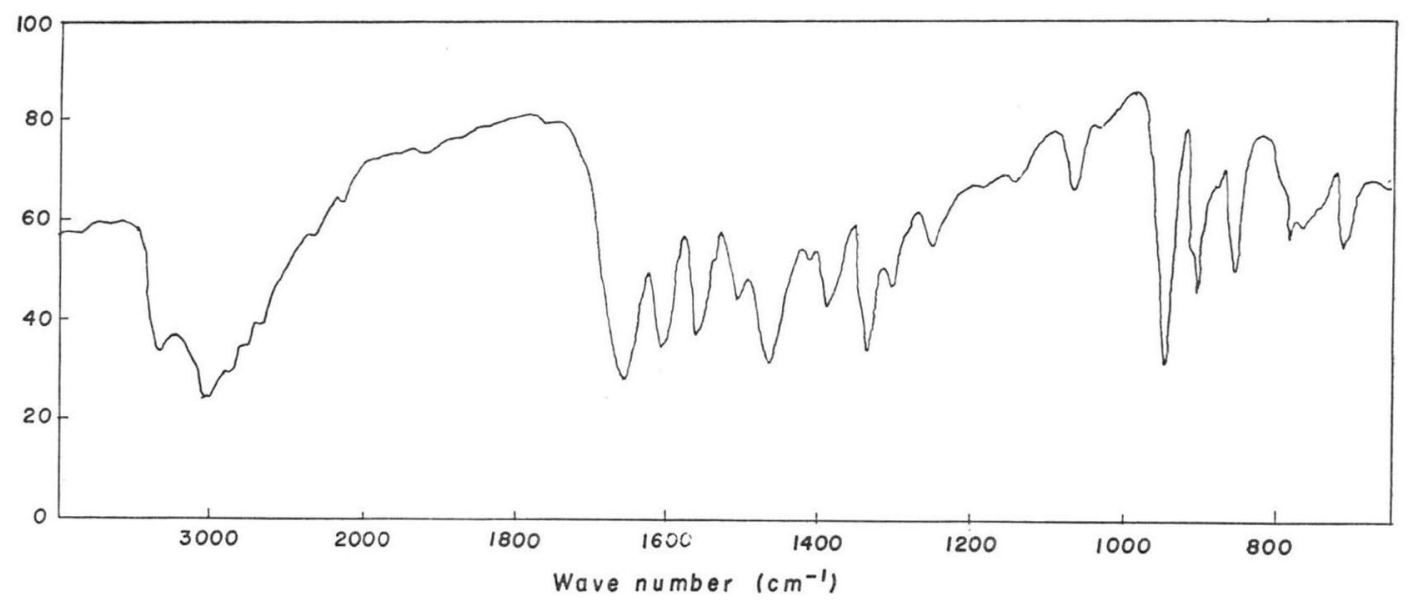

Formycin 5'-monophosphate $(240 \mathrm{mg})$ was dissolved in $20 \mathrm{ml}$ of distilled water, to which $8 \mathrm{~g}$ of resin (Dowex $50 \times 4,100 \sim 200$ mesh, $\mathrm{H}^{+}$form) was added. The mixture was refluxed for 40 minutes at $100^{\circ} \mathrm{C}$ and cooled. The aqueous solution and washings of the resin with $0.1 \mathrm{~N}$ $\mathrm{NH}_{4} \mathrm{OH}$ were pooled and concentrated in vacuo at a temperature below $40^{\circ} \mathrm{C}$ to give brownish paste. The paste was dissolved in a small volume of distilled water and applied on a waterjacketed column $\left(\phi 7 \mathrm{~mm} \times 50 \mathrm{~cm} ; 35^{\circ} \mathrm{C}\right)$ of Dowex $1 \times 4(200 \sim 400 \mathrm{mesh})$ in the chloride form. The column was washed with $200 \mathrm{ml}$ of distilled water, then $150 \mathrm{ml}$ of $0.01 \mathrm{~N} \mathrm{HCl}$ and eluted with $0.1 \mathrm{~N} \mathrm{HCl}$ at a flow rate of $30 \mathrm{ml}$ per hour. The fractions (fraction Nos. $5 \sim 8,10 \mathrm{ml}$ / fraction) containing formycin B 5'-monophosphate were combined and concentrated in vacuo $\left(40^{\circ} \mathrm{C}\right)$ to give white powder. The powder was dissolved in distilled water and the solution was acidified to $\mathrm{pH} 2$ with conc. $\mathrm{HCl}$. The acidic solution was mixed with $300 \mathrm{mg}$ of active carbon and allowed to stand for several hours at room temperature. The active carbon was collected on a grass-filter (G-4), washed with $100 \mathrm{ml}$ of distilled water and the elution was made with alkaline ethanol solution $\left(\mathrm{EtOH}-\mathrm{NH}_{4} \mathrm{OH}-\mathrm{H}_{2} \mathrm{O}, 50: 5: 45, \mathrm{v} / \mathrm{v}\right)$. By concentrating the eluate in vacuo $\left(40^{\circ} \mathrm{C}\right)$, white powder $(145 \mathrm{mg})$ was obtained. The white powder was dissolved in distilled water and the solution was saturated with $n$-butanol. The solution was kept at $5^{\circ} \mathrm{C}$ overnight and white precipitate formed was collected, followed by washing with $n$-butanol saturated water. The precipitate was dried in vacuo over silica gel and the white amorphous powder $(115 \mathrm{mg})$ was obtained. As shown in Fig. 1, the infrared spectrum of the preparation was well coincident with that of formycin B 5'-monophosphate reported by SAwA et al. ${ }^{16)}$ It was also confirmed that ultraviolet spectrum and melting point of the preparation were similar to those of formycin B 5'-monophosphate. ${ }^{13)}$

The $\mathrm{U}_{-}{ }^{14} \mathrm{C}$-aspartate and $\mathrm{U}_{-14}{ }^{14} \mathrm{C}$-fumarate were purchased from Daiichi Pure Chemical Co., Ltd. GTP and GDP were obtained from Sigma Chemical Co., Ltd. Other reagents used were from commercial sources and were of analytical grade.

\section{Results}

\section{Conversion of Formycin B to Formycin in Replacement Culture}

Since it was confirmed that aspartate, glutamate or lysine showed the stimulative effect on the biosynthesis of formycin ${ }^{8)}$, these amino acids and other compounds were respectively added at a concentration of $10 \mathrm{~mm}$ to the basal medium (glucose, $10 \mathrm{~mm} ; \mathrm{MgSO}_{4} \cdot 7 \mathrm{H}_{2} \mathrm{O}, 10 \mathrm{~mm}$; 
phosphate buffer, $\mathrm{pH} 7.0,100 \mathrm{~mm}$ and formycin $\mathrm{B}, 1 \mathrm{mg} / \mathrm{ml}, 3.6 \mathrm{~mm})$, and replacement cultures were performed for 2 hours at $27^{\circ} \mathrm{C}$. The results shown in Table 1 indicated that aspartate

Table 1. Effects of various compounds on the conversion of formycin B to formycin in replacement culture

\begin{tabular}{l|c}
\hline $\begin{array}{c}\text { Compound added } \\
(10 \mathrm{~mm})\end{array}$ & $\begin{array}{c}\text { Formycin formed } \\
(\mu \mathrm{g} / \mathrm{ml})\end{array}$ \\
\cline { 2 - 2 } None & 75 \\
$\mathrm{NH}_{4} \mathrm{Cl} *$ & 86 \\
Glycine & 63 \\
Serine & 75 \\
Lysine & 75 \\
Aspartate & 125 \\
Asparagine & 71 \\
Glutamate & 90 \\
Glutamine & 75 \\
\hline
\end{tabular}

* $\mathrm{NH}_{4} \mathrm{Cl}$ was added at a concentration of $20 \mathrm{~mm}$.

may act as an efficient amino donor in the conversion of formycin B to formycin. Unless otherwise noted, the basal medium supplemented with aspartate $(10 \mathrm{~mm})$ was employed as the conversion-medium throughout the successive experiments for the conversion. Since aspartate has been known as one of the substrates which are required in adenylosuccinate synthesis by adenylosuccinate synthetase ${ }^{11)}$, it might be possible to estimate that formycin B may be converted to formycin by an enzyme system including adenylosuccinate synthetase and adenylosuccinate lyase. It has been reported that sodium fluoride and adenosine or guanosine derivatives inhibit the activity of adenylosuccinate synthetase ${ }^{17-20)}$ and these purine derivatives also inhibit the action of adenylosuccinate lyase. ${ }^{21}$ In the preliminary experiments in authors' laboratory, moreover, DFA-4 was found to inhibit the biosynthesis of formycin. The inhibitory effects of these compounds on the conversion were studied in replacement culture. As shown in Table 2, the inhibition by DFA-4 was the most significant. In addition, adenine and guanosine were also inhibitory. On the other hand, other compounds including sodium fluoride had little or no effect on the conversion.

\section{Partial Purification of Formycin B-aminating Enzyme(s), Adenylosuccinate}

\section{Synthetase and Adenylosuccinate Lyase}

To examine the effects of DFA-4 and sodium fluoride on adenylosuccinate synthetase and adenylosuccinate lyase, purification of these enzymes was carried out. In the course of purification studies with strain MA406-A-1, it was found that novel enzyme(s) catalyzing the amination of formycin B was present in the organism. The partial purification of these three enzymes was performed as described below.

All operations were carried out at $0 \sim 5^{\circ} \mathrm{C}$ and glycine buffer $(\mathrm{pH}$ 8.5) was used as the buffer solution throughout the purification procedures. Bacterial cells obtained from a 2-liter 
culture were washed three times with $10 \mathrm{~mm}$ buffer, suspended in $60 \mathrm{ml}$ of the same buffer, and $30 \mathrm{ml}$ each of the suspension was exposed to sonic oscillation $(20 \mathrm{kHz}$; Ohtake sonicator) for 20 minutes with stirring.

The sonicate was centrifuged at $12,000 \times g$ for 20 minutes to remove intact cells and debris. When the cell-free extract $(45 \mathrm{ml})$ thus obtained was used as the enzyme sourse, none of the three enzyme activities was detectable. Indeed, the remarkable activities of the enzymes catalyzing the deamination of formycin and the transformation of aspartate and fumarate were detected in the cell-free extract. To remove the interfering enzymes, further treatment with acetic acid was done. The cell-free extract was carefully adjusted to $\mathrm{pH} 4.5$ with $0.1 \mathrm{~N}$ acetic acid, allowed to stand for 1 hour, and the precipitates were collected by centrifugation at $10,000 \times g$ for 10 minutes. The precipitates were dissolved in $10 \mathrm{ml}$ of $1 \mathrm{~mm}$ buffer and dialyzed for 30 hours against $500 \mathrm{ml}$ of the same buffer. The dialyzed solution (acid precipitated fraction, $11 \mathrm{ml}$ ) contained formycin B-aminating enzyme(s), adenylosuccinate synthetase and adenylosuccinate lyase, but none of the interfering enzymes. The acid precipitated fraction was fractionally precipitated at 20, 35, 45 and 55\% saturation of ammonium sulfate. The precipitates formed between $20 \sim 35 \%$ saturation and $45 \sim 55 \%$ saturation were collected by centrifugation at $10,000 \times \mathrm{g}$, dissolved in $10 \mathrm{ml}$ each of $1 \mathrm{~mm}$ buffer, and dialyzed overnight against $1,000 \mathrm{ml}$ of $0.1 \mathrm{~mm}$ buffer. The dialyzed solution containing the protein precipitated between $20 \sim 35 \%$ saturation was found to include the adenylosuccinate synthetase and adedylosuccinate lyase (ammonium sulfate fraction, $20 \sim 35 \%$ sat., $11 \mathrm{ml}$ ). In the dialyzed solution which contained the protein precipitated between $45 \sim 55 \%$ saturation, the activity of formycin B-aminating enzyme(s) was detected (ammonium sulfate fraction, $45 \sim 55 \%$ sat., 12 $\mathrm{ml})$. To the ammonium sulfate fraction $(45 \sim 55 \%$ sat.) was added $10 \mathrm{ml}$ of calcium phosphate gel $^{22)}$ (15 mg dry weight $/ \mathrm{ml}$ ) and, after 20 minutes of gentle stirring, the suspension was centrifuged at $5,000 \times g$ for 5 minutes to discard the supernatant. The gel was washed once with $20 \mathrm{~mm}$ buffer and formycin B-aminating enzyme(s) was eluted from the gel twice with $5 \mathrm{ml}$ each of $100 \mathrm{~mm}$ buffer. The eluates were pooled and dialyzed overnight against $1,000 \mathrm{ml}$ of $1 \mathrm{~mm}$ buffer. The dialyzed solution was used as a final preparation of formycin B-aminating enzyme(s) (calcium phosphate gel fraction, $8 \mathrm{ml}$ ). The results of the purification procedures for the aminating enzyme(s) are summarized in Table 3. For the separation of adenylosuccinate synthetase and adenylosuccinate lyase, the ammonium sulfate fraction $(20 \sim 35 \%$ sat.) was mixed with $20 \mathrm{ml}$ of the calcium phosphate gel, stirred gently for 20 minutes, and adenylosuccinate synthetase was recovered from the gel by eluting with $5 \mathrm{ml}$ of $0.5 \mathrm{~mm}$ buffer (final preparation of adenylosuccinate synthetase, $4 \mathrm{ml}$ ). To the residual gel was added $20 \mathrm{ml}$

Table 3. Purification of formycin B-aminating enzyme(s)

\begin{tabular}{l|c|c|c|c|c}
\hline \multicolumn{1}{c|}{ Fraction } & $\begin{array}{c}\text { Total protein } \\
\text { (mg) }\end{array}$ & $\begin{array}{c}\text { Total activity } \\
\text { (unit) }\end{array}$ & $\begin{array}{c}\text { Specific activity } \\
\text { (unit/mg protein) }\end{array}$ & $\begin{array}{c}\text { Purification } \\
\text { (fold) }\end{array}$ & $\begin{array}{c}\text { Yield } \\
(\%)\end{array}$ \\
\cline { 1 - 2 } Cell-free extract & 1,410 & trace & - & - & - \\
Acid precipitation & 255 & 77 & 0.3 & 1.0 & 100 \\
Ammonium sulfate & 95 & 65 & 0.7 & 2.5 & 84 \\
$\begin{array}{l}\text { (45 55\% sat.) } \\
\text { Calcium phosphate gel }\end{array}$ & 16 & 37 & 2.3 & 7.7 & 48 \\
\hline
\end{tabular}


of $300 \mathrm{~mm}$ buffer and centrifuged at $5,000 \times \mathrm{g}$ for 5 minutes to discard the supernatant. Adenylosuccinate lyase was then eluted from the gel with $5 \mathrm{ml}$ of $500 \mathrm{~mm}$ buffer and dialyzed overnight against $550 \mathrm{ml}$ of $1 \mathrm{~mm}$ buffer (final preparation of adenylosuccinate lyase, $4.5 \mathrm{ml}$ ).

\section{Characteristics of the Purified Enzymes}

Stoichiometry of the reaction catalyzed by formycin B-aminating enzyme(s).

The stoichiometry of the formycin formation was studied with purified formycin B-aminating enzyme(s). As shown in Table 4, it was revealed that the consumption of formycin B was accompanied by the equimolar disappearance of aspartate and appearance of formycin and fumarate.

Table 4. Stoichiometry of formycin formation from formycin B

The reaction mixture consisted of formycin B $(15 \mathrm{~mm}), \mathrm{U}^{14}{ }^{14} \mathrm{C}$-aspartate $(30 \mathrm{~mm}, 0.3 \mu \mathrm{Ci} / \mu \mathrm{mole})$, $\mathrm{MgSO}_{4}(10 \mathrm{~mm})$, glycine buffer $(\mathrm{pH} 8.5,50 \mathrm{~mm})$ and the purified enzyme. An aliquot of the reaction mixture was mixed immediately with perchloric acid and the remainders were incubated for 60 and 180 minutes, respectively. Formycin B concentration was determined by spectrophotometric measurement at $280 \mathrm{~nm}$ after paperchromatographic isolation of formycin B with a solvent system of $n$-butanol, acetic acid and water $(5: 1: 4, \mathrm{v} / \mathrm{v})$. Other methods employed were the same as those described in Materials and Methods.

\begin{tabular}{l|c|c|c|c|c}
\hline \multirow{2}{*}{ Compound } & \multirow{2}{*}{$\begin{array}{c}0 \text { minute } \\
\mu \text { moles } / \mathrm{ml}\end{array}$} & \multicolumn{2}{|c|}{60 minutes } & \multicolumn{2}{|c}{180 minutes } \\
\cline { 5 - 6 } & & $\mu$ moles $/ \mathrm{ml}$ & $\Delta$ & $\mu$ moles $/ \mathrm{ml}$ & $\Delta$ \\
\cline { 6 - 6 } Formycin B & 14.82 & 13.20 & -1.62 & 11.10 & -3.72 \\
Aspartate & 31.76 & 30.18 & -1.58 & 28.07 & -3.69 \\
Formycin & 0.00 & 1.52 & +1.52 & 3.78 & +3.78 \\
Fumarate & 0.00 & 1.56 & +1.56 & 3.96 & +3.96 \\
\hline
\end{tabular}

Substrate specificity of formycin B-aminating enzyme(s).

The formycin B-aminating enzyme(s) did not catalyze the amination of formycin B 5'monophosphate, hypoxanthine, inosine or IMP in the presence or absence of $0.5 \mathrm{~mm}$ GTP, but catalyzed specifically the amination of formycin B. It was found that $\mathrm{Mg}^{2+}$ may be required for the reaction and neither $\mathrm{K}^{+}, \mathrm{Na}^{+}, \mathrm{Mn}^{2+}$ and $\mathrm{Ca}^{2+}$ took the place of $\mathrm{Mg}^{2+}$.

Effects of DFA-4 and sodium fluoride on the purified enzymes.

As shown in Table 5, sodium fluoride inhibited the action of adenylosuccinate synthetase and did not inhibit that of adenylosuccinate lyase or formycin B-aminating enzyme(s). On the

Table 5. Effect of DFA-4 and sodium fluoride on the purified enzymes

\begin{tabular}{l|c|c|c|c}
\hline \multirow{2}{*}{$\begin{array}{c}\text { Compound } \\
\text { added }\end{array}$} & $\begin{array}{c}\text { Concentration } \\
(\mathrm{mm})\end{array}$ & $\begin{array}{c}\mid c \\
\text { Formycin B aminating } \\
\text { enzyme(s) }\end{array}$ & $\begin{array}{c}\text { Adenylosuccinate } \\
\text { synthetase }\end{array}$ & $\begin{array}{c}\text { Adenylosuccinate } \\
\text { lyase }\end{array}$ \\
\hline None & - & 100 & 100 & 100 \\
DFA-4 & 1 & 14 & 102 & 95 \\
Sodium fluoride & 10 & 5 & 95 & 102 \\
& 1 & 98 & 61 & 94 \\
\hline
\end{tabular}


other hand, DFA-4 was found to be a potent inhibitor of formycin B-aminating enzyme(s), whereas this compound showed no inhibitory effect on adenylosuccinate synthetase or adenylosuccinate lyase. It was also observed that, in the presence of $10 \mathrm{~mm}$ adenine, adenosine, guanine or guanosine, $88,41,35$ or $12 \%$ inhibition was detected, respectively. No inhibition or stimulation of the amination reaction was effected by $10 \mathrm{~mm}$ AMP, ADP, ATP, GMP, GDP, GTP, hypoxanthine, inosine, IMP, formycin B 5'-monophosphate. These results described above and those shown in Table 2 suggested a participation of formycin B-aminating enzyme(s) in the formation of formycin from formycin B.

\section{Conversion of Formycin B to Formycin by Adenine Auxotrophs}

Using the adenine auxotrophs, the conversion ratio of formycin B to formycin in replacement culture and the specific activities of formycin B-aminating enzyme(s), adenylosuccinate synthetase and adenylosuccinate lyase were determined. As shown in Table 6, the auxotrophic

Table 6. The conversion ratio of formycin B to formycin by adenine auxotrophs and the activities of the related enzymes

\begin{tabular}{|c|c|c|c|c|}
\hline \multirow{2}{*}{ Strain } & \multicolumn{3}{|c|}{ Specific activities in acid precipitated fraction (units/mg protein) } & \multirow{2}{*}{$\begin{array}{l}\text { Molar conversion ratio } \\
\text { of formycin B to } \\
\text { formycin in replace- } \\
\text { ment culture* }(\%)\end{array}$} \\
\hline & $\begin{array}{c}\text { Formycin B aminating } \\
\text { enzyme }(s)\end{array}$ & $\begin{array}{l}\text { Adenylosuccinate } \\
\text { synthetase }\end{array}$ & $\begin{array}{l}\text { Adenylosuccinate } \\
\text { lyase }\end{array}$ & \\
\hline Parent & 0.32 & 0.24 & 0.22 & 36 \\
\hline No. 55 & 0.28 & 0.02 & 0.26 & 28 \\
\hline No. 71 & 0.41 & 0.29 & 0.01 & 48 \\
\hline
\end{tabular}

* Replacement culture was performed for 9 hours at $27^{\circ} \mathrm{C}$. Molar conversion ratio was calculated as indicated in Table 2.

strains No. 55 and No. 71 lacking, respectively, adenylosuccinate synthetase and adenylosuccinate lyase readily converted formycin B to formycin in replacement culture. It was again estimated that formycin B-aminating enzyme(s) would convert formycin B to formycin without participation of the enzyme system including adenylosuccinate synthetase and adenylosuccinate lyase.

\section{Discussion}

It has been estimated, in $N$. interforma, that formycin may be formed by dephosphorylation of formycin $5^{\prime}$-monophosphate which was considered to be produced from formycin $\mathbf{B} 5^{\prime}$ monophosphate by two successive actions of adenylosuccinate synthetase and adenylosuccinate lyase. ${ }^{\text {) }}$ Although the question of whether the amination of formycin B to formycin is due to one or two enzymes is yet unresolved, the formycin B-aminating enzyme(s) catalyzing the reaction of the following equation was found in $S$. sp. MA406-A-1.

$$
\text { formycin } \mathrm{B}+\text { aspartate } \rightarrow \text { formycin }+ \text { fumarate }
$$

This finding led the authors to speculate that formycin may be formed by amination of formycin B, but not by the dephosphorylation of formycin $5^{\prime}$-monophosphate.

It was also found that, in the presence of GTP and aspartate, the adenylosuccinate synthetase of the strain MA406-A-1 could utilize formycin B 5'-monophosphate as substrate with 
$10 \%$ of specific activity of that for IMP, and did not utilize formycin B in the presence or absence of GTP. When sodium fluoride was added at a concentration of 1 or $10 \mathrm{~mm}$ to the assay system containing formycin B 5'-monophosphate instead of IMP, the 90 or $95 \%$ inhibition was observed, respectively, and it was indicated that the synthetase did not play an important role in the formation of formycin from formycin B. This indication was supported by the fact that adenine auxotrophic mutant lacking the synthetase readily converted formycin B to formycin in replacement culture (Table 6). When formycin 5'-monophosphate was substituted for AMP, the specific activity of the adenylosuccinate lyase was consistently decreased to $5 \%$ of that for AMP under various assay conditions. From the results shown in Table 6, the lyase, however, seemed not to participate in the conversion of formycin B to formycin. On the other hand, it can also be estimated that once formycin B 5'-monophosphate or formycin 5'-monophosphate was formed in vivo, the synthetase and the lyase may catalyze the interconversion of these nucleotide derivatives as well as purine nucleotides.

It was very interesting that the amination of formycin B, with aspartate as an amino donor, occurred in the absence of GTP which was required, even when formycin 5'-monophosphate was substituted for IMP, in the reaction catalyzed by adenylosuccinate synthetase. To elucidate the detailed mechanism of the amination of formycin B to formycin, further purification of formycin B-aminating enzyme(s) and the kinetic studies would be necessary.

In spite of the existence of strong adenosine deaminase activity which was confirmed to catalyze the deamination of formycin to formycin B, in the cell-free extract prepared from the washed cells, the conversion of formycin to formycin B was not observed in replacement culture with these cells. It is probable that the inhibitor of adenosine deaminase, i.e. coformycin, which was isolated from the cultured broth of formycin-producing strains and was found to be a potent inhibitor of the deaminase ${ }^{23-28)}$, inhibited the intracellular deamination of formycin to formycin B.

\section{Acknowledgments}

The authors express their appreciations to Dr. Y. OKамI for his interest and encouragement, and to Mrs. S. Kikuchi, K. Hikiji and Miss. Y. Kawabata for their contribution to this study. Their thanks are also due to Dr. T. NiIDA for his kind supply of the authentic formycin and formycin B.

\section{References}

1) Hori, M.; E. Ito, G. Koyama, T. Takeuchi \& H. Umezawa: A new antibiotic, formycin. J. Antibiotics, Ser. A 17: 96 99, 1964

2) Koyama, G.; K. Maeda, H. Umezawa \& Y. Iitake: The structural studies of formycin and formycin B. Tetrahedron Letters 1966: 597 602, 1966

3) Robins, R.K.; L.B. Townsend, F. Cassidy, J.F. Gerster, A.L. Lewis \& R.L. Miller: Structure of nucleoside antibiotics, formycin, formycin B and laurusin. J. Heterocycl. Chem. 3: 110 114, 1966

4) Townsend, L.B. \& R. K. Robins: The mass spectra of formycin, formycin B and showdomycin carbon linked nucleoside antibiotics. J. Heterocycl. Chem. 6: 459 464, 1969

5) Aizawa, S.; T. Hidaka, N. Otake, H. Yonehara, K. Isono, N. Igarashi \& S. Suzuki: Studies on a new antibiotic, laurusin. Agr. Biol. Chem. 29: 375 376, 1965

6) Japanese Patent No. 10,928, 1967 (Nippon Kayaku Co., Ltd.)

7) Kunimoto, T.; T. Sawa, T. Wakashiro, M. Hori \& H. Umezawa: Biosynthesis of the formycin family. J. Antibiotics 24: 253 258, 1971

8) Ochi, K.; S. Iwamoto, E. Hayase, S. Yashima \& Y. Okami: Biosynthesis of formycin. Role of certain amino acids in formycin biosynthesis. J. Antibiotics 27: 909 916, 1974

9) Sawa, T.; Y. Fukagawa, I. Homma, T. Wakashiro, T. Takeuchi, M. Hori \& T. Komai: Metabolic conversion of formycin B to formycin A and oxoformycin B in Nocardia interforma. J. Antibiotics 21: $334 \sim 339,1968$

10) Adelberg, E.A.; M. Mandel \& G.C.C. Chen: Optimal conditions for mutagenesis by N-methyl- 
$\mathrm{N}^{\prime}$-nitro-N-nitrosoguanidine in Escherichia coli K-12. Biochem. Biophys. Res. Commun. 18: 788 792, 1965

11) Lieberman, I.; Enzymatic synthesis of adenosine 5'-phosphate from inosine 5'-phosphate. J. Biol. Chem. 223: 327 339, 1956

12) Carter, C. E.; Adenylosuccinase and adenylosuccinic acid. Methods in enzymology. Vol. 6. ed. by S.P. Colowick \& N.O. Kaplan, pp. 789 792, Academic Press, New York, 1963

13) Kawamura, K.; S. Fukatsu, M. Murase, G. Koyama, K. Maeda \& H. Umezawa: The studies on the degradation products of formycin B. J. Antibiotics, Ser. A 19: 91 92, 1966

14) Lowry, O.H.; N. J. Rosebrough, A. L. Farr \& R. J. Randall: Protein measurement with the Folin phenol reagent. J. Biol. Chem. 193: 265 275, 1951

15) Ward, D.C.; A. Cerami, E. Reich, G. Acs \& L. Altwerger: Biochemical studies of nucleoside analogue, formycin. J. Biol. Chem. 244: 3234 3250, 1969

16) Sawa, T.; Y. Fukagawa, Y. Shimauchi, K. Ito, M. Hamada, T. Takeuchi \& H. Umezawa: Studies on formycin and formycin B phosphates. J. Antibiotics, Ser. A 18: 259 266, 1965

17) Lieberman, I.: Amination of IMP. Adenylosuccinate synthetase. Methods in enzymology. Vol. 6. ed. by P.O. Colowick \& N.O. Kaplan, pp. 100 102, Academic Press, New York, 1963

18) WyngaArden, J.B. \& R. A. Greenland: The inhibition of adenylosuccinate kinosynthetase of Escherichia coli by adenosine and guanosine 5'-monophosphates. J. Biol. Chem. 238: 1054 1057, 1963

19) Ishir, K. \& I. Shrro.: Regulation of purine ribonucleotide synthesis by end product inhibition. Effect of purine ribonucleotides on succino-AMP synthetase of Bacillus subtilis. J. Biochem, (Tokyo). 68: $171 \sim 176,1970$

20) NAGy, M.; M. DJembo-TAty, \& H. Heslot: Regulation of the biosynthesis of purine nucleotides in Shizosaccharomyces pombe. III. Kinetic studies of adenylosuccinate synthetase. Biochim. Biophys. Acta 309: 1 10, 1973

21) Ratner, S.: Arginosuccinase and adenylosuccinase. Enzymes. Vol. 7. ed. by P.D. Boyer, pp. 167 197, Academic Press, New York, 1972

22) Tsuboi, K. K. \& P. B. Hudson: Enzymes of the human erythrocyte. I. Purine nucleoside phosphorylase; isolation procedure. J. Biol. Chem. 224: 879 887, 1957

23) Nidda, T.; T. Niwa, T. Tsuruoka, N. Ezaki, T. Shomura \& H. Umezawa: Isolation and characteritics of coformycin. The 153rd scientific meeting of Jap. Antibiot. Res. Assoc., Jan. 27, 1967

24) Sawa, T.; T. Fukagawa, I. Honma, T. Takeuchi \& H. Umezawa: Mode of inhibition of coformycin on adenosine deaminase. J. Antibiotics, Ser. A 20: 227 231, 1967

25) Ohno, M.; N. Yagisawa, S. Shibahara, S. Kondo, K. Maeda \& H. Umezawa: Synthesis of coformycin. J. Am. Chem. Soc. 96: 4326 4327, 1974

26) Nakamura, H.; G. Koyama, Y. Iitaka, M. Ohno, N. Yagisawa, S. Kondo, K. Maeda \& H. UMEZawa: Structure of coformycin, as unusual nucleoside of microbial origin. J. Am. Chem. Soc. 96: 4327 4328, 1974 